\title{
Orofaciolingual dyskinesia due to diphenylhydantoin sodium
}

\author{
Chandrasekharan Rajasekharan, ${ }^{1}$ Adlene Manue Tina, ${ }^{2}$ Sanu Watson Renjith ${ }^{2}$
}

${ }^{1}$ Department of Internal Medicine, Medical College Hospital, Thiruvananthapuram, Kerala, India

${ }^{2}$ Department of Internal Medicine, Medical College Hospital, Thiruvananthapuram, Kerala, India

\section{Correspondence to}

Professor Chandrasekharan

Rajasekharan,

drcrajasekharan@yahoo.com

\section{DESCRIPTION}

A 60-year-old woman was referred to our emergency services with a 2-day history of abnormal facial movements. She had been in a recent road traffic accident following which she developed subarachnoid haemorrhage and had seizures. She was on oral diphenylhydantoin sodium $100 \mathrm{mg}$ thrice daily for the last 17 days. She was not on antipsychotics or any other antidopaminergic drugs.

On examination, she was conscious and alert. Her pulse rate was $80 / \mathrm{min}$, regular, blood pressure $120 / 80 \mathrm{~mm} \mathrm{Hg}$ and temperature $98.4^{\circ} \mathrm{F}$. Higher mental functions were normal and cranial nerves examination was normal. Her pupils were equal and normal reacting to light. Abnormal dyskinetic movements of face, perioral area, eye lids, nystagmus and choreiform movement of the tongue were present (video 1). At times she found it difficult to keep her tongue inside her mouth or to talk properly. These symptoms were absent during sleep. No palatal or ocular myoclonus was seen. There were no signs of cerebellar dysfunction. Plantar response was flexor bilaterally. Other systems and breast examination were normal. Her neuroimaging scan revealed no structural abnormalities. The renal function and liver function tests and other biochemical parameters were normal. The serum phenytoin was $34 \mu \mathrm{g} / \mathrm{ml}$ (therapeutic range: $10-20 \mu \mathrm{g} / \mathrm{ml}$ ). She was diagnosed with orofaciolingual dyskinesia due to phenytoin toxicity.

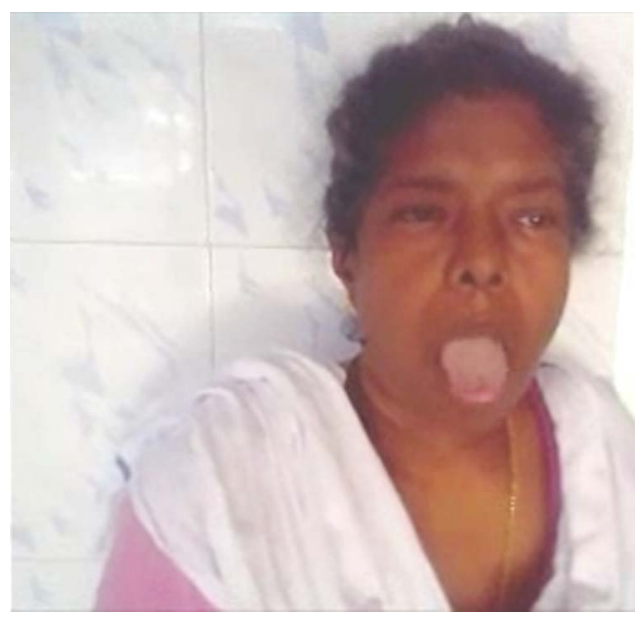

Video 1 Showing random irregular orofaciolingual choreiform dyskinesias.
Oral phenytoin was stopped and she was started on tablet trihexyphenidyl $2 \mathrm{mg}$ twice daily and clonazepam $0.5 \mathrm{mg}$ at bedtime, which was continued.

Symptoms persisted even 1 week after discontinuing phenytoin and a repeat serum phenytoin showed $20 \mu \mathrm{g} / \mathrm{ml}$ (therapeutic range $10-20 \mu \mathrm{g} / \mathrm{ml}$ ). By the second week, her symptoms showed steady resolution and on the third week she was totally asymptomatic.

\section{Learning points}

- Cerebellar ataxia is a well-described complication of phenytoin toxicity. But orofacial dyskinesia is a known side effect of tricyclic antidepressants, antipsychotics and antiemetics.

- Dyskinesia is a recognised but uncommon side effect of treatment with phenytoin. ${ }^{1}$ It has been reported even in therapeutic range and by Luhdorf and Lund. ${ }^{2}$ It may persist for variable periods of time even on discontinuation of therapy.

- The hypothesised reason for phenytoin-induced hyperkinesia is the increasing dopaminergic and serotonergic activity in the basal ganglia. Patients with preexisting basal ganglia damage are the most susceptible to these side effects. ${ }^{3}$

Contributors RC was a primary clinician under whom the patient was admitted, investigated and treated. RSW was an associate professor, in charge of the case. TMA was the resident in charge of the case. All the authors had an equal role in writing, editing and formatting the manuscript. PR was a fourth year elective who presented the case and made a significant contribution in collecting all the references and producing the images.

Competing interests None.

Patient consent Obtained.

Provenance and peer review Not commissioned; externally peer reviewed.

\section{REFERENCES}

1 Harrison MB, Lyons GR, Landow ER. Phenytoin and dyskinesias: a report of two cases and review of the literature. Mov Disord 1993:8:19-27.

2 Luhdorf K, Lund M. Phenytoin-induced hyperkinesia. Epilepsia 1977;18:409-15.

3 Yoshidha M, Yamada Y, Ozaki Y, et al. Phenytoin induced orofacial dyskinesia. J Neurol 1985;231:340-2. 


\section{Images in...}

Copyright 2013 BMJ Publishing Group. All rights reserved. For permission to reuse any of this content visit http://group.bmj.com/group/rights-licensing/permissions.

BMJ Case Report Fellows may re-use this article for personal use and teaching without any further permission.

Become a Fellow of BMJ Case Reports today and you can:

- Submit as many cases as you like

- Enjoy fast sympathetic peer review and rapid publication of accepted articles

- Access all the published articles

- Re-use any of the published material for personal use and teaching without further permission

For information on Institutional Fellowships contact consortiasales@bmjgroup.com

Visit casereports.bmj.com for more articles like this and to become a Fellow 